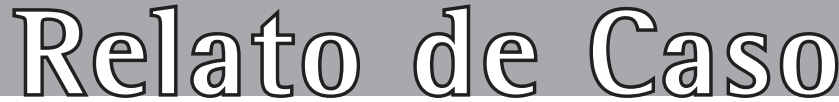

\section{Hereditary hemorrhagic telangiectasia: a rare cause of severe anemia ${ }^{*, * *}$}

\author{
Telangiectasia hemorrágica hereditária: uma causa rara de anemia grave \\ José Wellington Alves dos Santos', Tiago Chagas Dalcin², Kelly Ribeiro Neves², \\ Keli Cristina Mann ${ }^{3}$, Gustavo Luis Nunes Pretto ${ }^{4}$, Alessandra Naimaier Bertolazi ${ }^{5}$
}

\begin{abstract}
Hereditary hemorrhagic telangiectasia is an autosomal dominant disease in which arteriovenous communications are typically seen in the skin, mucosal surfaces, lungs, brain and gastrointestinal tract. This disease typically presents as epistaxis, gastrointestinal bleeding and arteriovenous malformations (in the brain and lungs). Although the epistaxis and gastrointestinal bleeding can result in anemia, patients diagnosed with hereditary hemorrhagic telangiectasia rarely present severe anemia. Herein, we report the case of a 49-year-old man with severe anemia and undiagnosed hereditary hemorrhagic telangiectasia.
\end{abstract}

Keywords: Hereditary hemorrhagic telangiectasia; Iron deficiency anemia; Case reports [publication type].

\section{Resumo}

Telangiectasia hemorrágica hereditária é uma doença autossômica dominante na qual comunicações arteriovenosas afetam comumente pele, superfícies mucosas, pulmões, cérebro e trato gastrointestinal. As manifestações comuns desta doença são epistaxe, sangramento gastrointestinal, e malformações arteriovenosas cerebrais e pulmonares. Apesar de a epistaxe e o sangramento gastrointestinal poderem causar anemia, telangiectasia hemorrágica hereditária raramente é diagnosticada com anemia grave. Neste artigo é relatado o caso de um homem de 49 anos de idade com telangiectasia hemorrágica hereditária não diagnosticada e anemia grave.

Descritores: Telangiectasia hemorrágica hereditária; Anemia ferropriva; Relatos de casos [tipo de publicação].

\section{Introduction}

Identified nearly a century ago, hereditary hemorrhagic telangiectasia (HHT) is an autosomal dominant inherited disease in which abnormal arteriovenous communications, the so-called telangiectasias, typically affect the skin, nose, mucosal surfaces, lungs, brain and gastrointestinal tract. ${ }^{(1-4)}$ The worldwide incidence of HHT has been calculated to be between $1 / 5000$ and $1 / 10,000$ persons. ${ }^{(5)}$ Currently, HHT is seen in varying proportions in patients suffering from the following conditions: in 90\% of patients with epistaxis; in $80 \%$ of patients with telangiectasia of the skin, lip or mouth; in 30\% of patients with pulmonary arteriovenous malformations (AVMs); in <30\% of patients with hepatic AVMs; in 15\% of patients with gastrointestinal bleeding; in
$10 \%$ of patients with cerebral AVMs and in $1 \%$ of patients with spinal AVMs. ${ }^{(6,7)}$ Clinical diagnosis is based on the presence of at least three of the following characteristics: recurrent epistaxis; mucocutaneous telangiectasias; evidence of autosomal dominant inheritance; and visceral AVMs. ${ }^{(3,4,8)}$ In rare cases, HHT can cause anemia, although such HHTrelated anemia is generally mild to moderate. ${ }^{(6)}$ Herein, we present a case of severe anemia concomitant with HHT.

\section{Case report}

A 49-year-old man presented for medical treatment with a 30-year history of recurrent epistaxis, which had become less frequent in the last years. He also reported

\footnotetext{
* This work was done at Federal University of Santa Maria - UFSM - Santa Maria (RS) Brazil.

1. Postdoctoral Fellow in Pulmonology. Head of the Pulmonology Department at the Santa Maria University Hospital, Federal University of Santa Maria - UFSM Santa Maria, (RS) Brazil.

2. Medical student at the Federal University of Santa Maria - UFSM - Santa Maria (RS) Brazil.

3. Medical resident in pulmonology at the Federal University of Santa Maria - UFSM - Santa Maria (RS) Brazil.

4. Medical resident in internal medicine at the Federal University of Santa Maria - UFSM - Santa Maria (RS) Brazil.

5. Masters Student in Pulmonology at the Federal University of Santa Maria - UFSM - Santa Maria (RS) Brazil.

Correspondence to: José Wellington Alves dos Santos. Rua Venâncio Aires, 2020/ 403, CEP 97010-004, Santa Maria, RS, Brazil.

Submitted 5/12/05. Accepted, after review: 17/3/06.

** A versão integral em português deste artigo é disponível no endereço www.jornaldepneumologia.com.br
} 
progressive fatigue and pallor over the last decade, together with progressive dyspnea, exacerbation of fatigue, pallor and weight loss of $6 \mathrm{~kg}$ over the preceding six months, as well as a family history of telangiectasias. He had no addictions and presented no hemoptysis or chest pain. In the physical examination, discolored mucosa, pallor, blood pressure of $110 / 70 \mathrm{mmHg}$ and a 2/6 systolic ejection murmur were observed, together with telangiectasias in the oral mucosa, lips (Figure 1) and palate. The chest was clear to auscultation, and there was no digital clubbing. The blood workup performed at admission revealed the following: iron deficiency anemia with hemoglobin of $3.8 \mathrm{~g} / \mathrm{dL}$; mean corpuscular volume: $58.5 \mathrm{fL}$; red cell size distribution: $32.6 \%$; and ferritin: $3.5 \mathrm{ng} / \mathrm{mL}$. The results of red cell, folate and vitamin $\mathrm{B}_{12}$ tests, as well as those of a clotting screen, were normal. The test for occult blood in feces was positive. The chest X-ray showed a well-circumscribed nodule of $1.5 \mathrm{~cm}$ in diameter in the right lower lung lobe and a $1-\mathrm{cm}$ nodule in the left middle lobe. These findings were consistent with pulmonary AVMs, which were confirmed through contrast-enhanced computed tomography scans of the chest (Figure 2). During complementary evaluation, endoscopy of the upper digestive tract indicated multiple gastric angiodysplasias (Figure 3). Echocardiography with agitated saline contrast medium was used to detect intracardiac or intrathoracic shunts. The echocardiogram revealed microbubbles in the left atrium within three cardiac cycles of their appearance in the right atrium, indicating intrapulmonary shunting. Cranial angiotomography, abdominal ultrasound and colonoscopy results were normal. A diagnosis of HHT was established. Two weeks of blood transfusions and iron therapy improved the anemia significantly, raising hemoglobin to $10 \mathrm{~g} / \mathrm{dL}$. After three months of outpatient evaluation, the patient remained symptom free.

\section{Discussion}

Some studies have demonstrated an association between HHT and severe anemia. However, from a total of 1641 articles, ${ }^{(5)}$ we found only 9 in which such an association was reported..$^{(9-17)}$ Those 9 studies involved a total of 20 patients with severe anemia and HHT; only 15\% were diagnosed during the severe anemia episode.

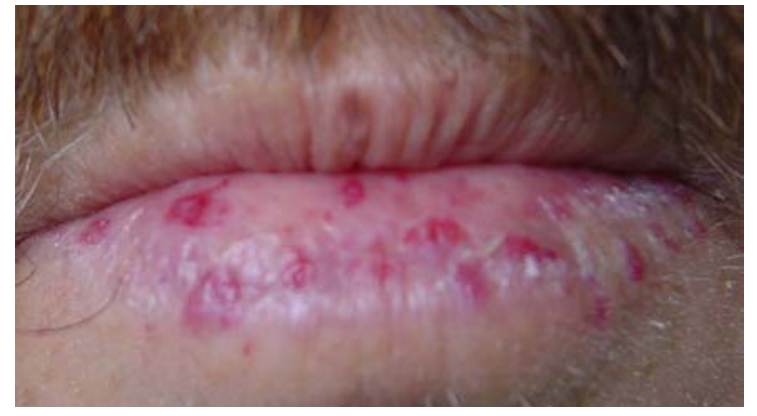

Figure 1 - Oral telangiectasias - Inferior lip with multiple telangiectasias.

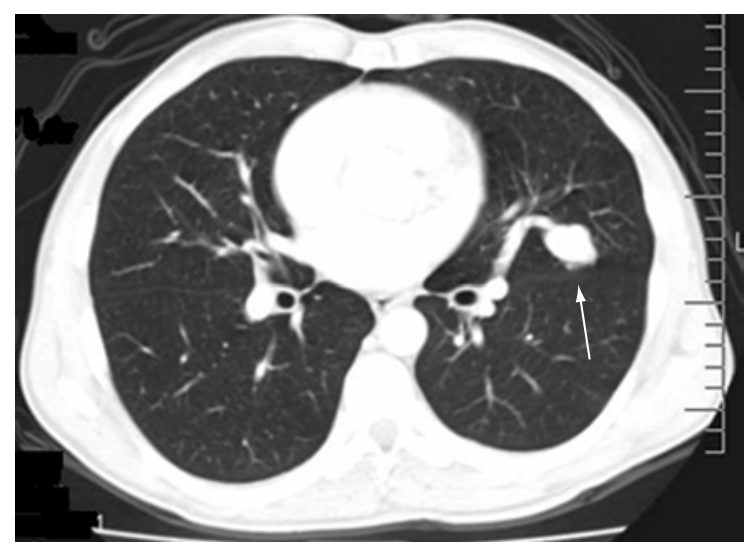

Figure 2 - Pulmonary arteriovenous fistula - Contrastenhanced thoracic computed tomography scan showing the left pulmonary arteriovenous malformation.

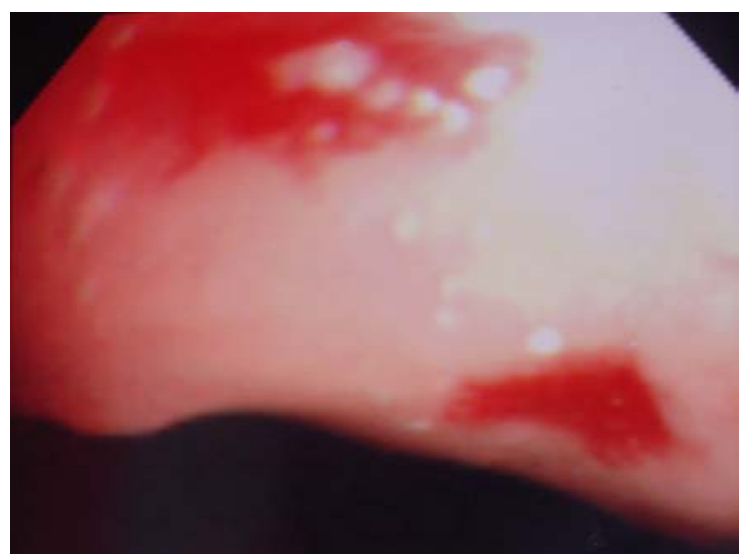

Figure 3 - Gastric angiodysplasia: endoscopy of the upper digestive tract showing gastric angiodysplasias. 
The clinical profile of HHT, a rare disease with a classic presentation, quite rarely includes severe anemia. Patients with HHT present normal hemostasis and platelet function, and the recurrent bleeding is therefore being related to the telangiectasias. ${ }^{(18)}$ The anemia can be due to one or both of two factors: recurrent epistaxis and gastrointestinal bleeding. ${ }^{(6,19-20)} \ln$ the previously mentioned 9 studies, the most common cause of severe anemia in patients with HHT was found to be chronic gastrointestinal bleeding (in 70\%), followed by epistaxis (in 25\%)..$^{(9-17)}$

Recurrent gastrointestinal tract hemorrhage occurs in up to one-third of individuals with HHT. The risk of such hemorrhage increases with advancing age, typically appearing in the fifth or sixth decade of life. ${ }^{(6)}$ Gastrointestinal telangiectasias can be multiple and are found throughout the gastrointestinal tract, most commonly in the stomach and duodenum. ${ }^{(5,6,10)}$ The severity of anemia is related to the number of telangiectasias, ${ }^{(10)}$ which are diagnosed through digestive endoscopy. ${ }^{(19)}$

The most common manifestation of HHT is epistaxis caused by spontaneous bleeding from telangiectasias in the nasal mucosa, which can be seen in individuals as young as 10 years of age and occur in most affected individuals. ${ }^{(3,4,18)}$ The telangiectasia can be so severe that multiple transfusions and oral iron supplementation are required or so mild that HHT is never suspected. ${ }^{(18)}$ Although recurrent epistaxis becomes more severe with advancing age in approximately two-thirds of all individuals with $\mathrm{HHT}_{,}^{(4)}$ the disorder can also go undetected for many years and might be less common in adults. ${ }^{(16)}$

Currently, there is no satisfactory treatment for HHT. Appropriate management depends on the clinical $\mathrm{m}$ anifestations and the site of the disease..$^{(7)}$ Treatment for bleeding is symptomatic and can require iron therapy and blood transfusions. Aspirin and other medicaments that impair hemostasis are contraindicated in such cases. ${ }^{(16)}$ Our patient required the combination of blood transfusions and iron therapy in order to treat the gastrointestinal bleeding.

It is highly unusual for HHT to be accompanied by severe anemia. Therefore the differential diagnosis in cases of severe anemia rarely includes HHT. Since the present case featured the typical as well as the atypical manifestations, it was promptly diagnosed and managed.

In summary, although HHT is a rare disease, it can be easily recognized due to its classic presentation in most patients. ${ }^{(2)}$ We emphasize the role of this disease as a cause of iron deficiency anemia and the importance of clinical investigation, together with timely diagnosis.

\section{References}

1. Halefoglu AM. Rendu-Osler-Weber syndrome presenting with pulmonary arteriovenous fistula. Australas Radiol. 2005;49(3):242-5.

2. Shovlin CL, Letarte M. Hereditary haemorrhagic telangiectasia and pulmonary arteriovenous malformations: issues in clinical management and review of pathogenic mechanisms. Thorax. 1999;54(8):714-29.

3. Peery WH. Clinical spectrum of hereditary hemorrhagic telangiectasia (Osler-Weber-Rendu disease). Am J Med. 1987;82(5):989-97.

4. Guttmacher AE, Marchuk DA, White Rl Jr. Hereditary hemorrhagic telangiectasia. $\mathrm{N}$ Engl $\mathrm{J}$ Med. 1995;333(14):918-24.

5. Sabba C. A rare and misdiagnosed bleeding disorder: hereditary hemorrhagic telangiectasia. J Thromb Haemost. 2005;3(10):2201-10.

6. Begbie ME, Wallace GM, Shovlin CL. Hereditary haemorrhagic telangiectasia (Osler-Weber-Rendu syndrome): a view from the 21st century. Postgrad Med J. 2003;79(927):18-24.

7. Massoud 01, Youssef Wl, Mullen KD. Resolution of hereditary hemorrhagic telangiectasia and anemia with prolonged alpha-interferon therapy for chronic hepatitis C. J Clin Gastroenterol. 2004;38(4):377-9.

8. Bayrak-Toydemir P, Mao R, Lewin S, McDonald J. Hereditary hemorrhagic telangiectasia: an overview of diagnosis and management in the molecular era for clinicians. Genet Med. 2004;6(4):175-91.

9. Takuwa T, Yoshioka S, Miyata Y, Fujisaki S, Zenke Y, Asahara T. Large pulmonary arteriovenous malformation with hyperammonemia. Jpn J Thorac Cardiovasc Surg. 2004;52(10):484-7.

10. Kjeldsen $A D$, Kjeldsen J. Gastrointestinal bleeding in patients with hereditary hemorrhagic telangiectasia. Am J Gastroenterol. 2000;95(2):415-8.

11. Gurevitch Y, Hasin Y, Gotsman MS, Rozenman Y. Coronary arteriovenous malformations in a patient with hereditary hemorrhagic telangiectasia-a case report. Angiology. 1998;49(7):577-80.

12. Berry DL, Deleon FD. Endometrial ablation for severe menorrhagia in a patient with hereditary hemorrhagic telangiectasia. A case report. J Reprod Med. 1996;41(3):183-5.

13. Hisada T, Kuwabara H, Tsunoda T, Kaneko K, Kubota S, Miwa $\mathrm{Y}$, et al. Hereditary hemorrhagic telangiectasia showing severe anemia which was successfully treated with estrogen. Intern Med. 1995;34(6):589-92.

14. Maruyama J, Watanabe M, Onodera S, Hasebe N, Yamashita $\mathrm{H}$, Tobise K. A case of Rendu-Osler-Weber disease with cerebral hemangioma, multiple pulmonary arteriovenous fistulas and hepatic arteriovenous fistula. Jpn J Med. 1989;28(5):651-6. 
15. Cronstedt J, Brechter C, Carling L. Coexistent hereditary haemorrhagic telangiectasia and primary thrombocythaemia-coincidence or syndrome? Acta Med Scand. 1982;212(4):261-5.

16. Findlay PF, Sutherland J. An unusual cause of anaemia. Postgrad Med J. 1998;74(876):617-8.

17. Valverde CP, Manzano DS, Águeda RY. Telangiectasia hemorrágica hereditaria como causa de anemia ferropénica. Rev Clin Esp. 1993;192: 483-4.
18. Shah RK, Dhingra JK, Shapshay SM. Hereditary hemorrhagic telangiectasia: a review of 76 cases. Laryngoscope. 2002;112(5):767-73.

19. Del Molino AP, Zarrabeitia R, Fernández A. Telangiectasia Hemorrágica Hereditaria. Med Clín (Barc). 2005;124(15):583-7.

20. Fontana S, Lammle B. [Chronic, hemorrhage-induced iron deficiency anemia in Osler disease] Ther Umsch. 1999;56(9):526-8. German. 